\title{
Nonunion fractures in small animals - A literature review
}

\section{Não união de fraturas em pequenos animais - Revisão de literatura}

\author{
Jaqueline França dos Santos ${ }^{1 *}$; Cássio Ricardo Auada Ferrigno²; \\ Ísis dos Santos Dal-Bó ${ }^{1}$; Daniela Fabiana Izquierdo Caquías ${ }^{3}$
}

\begin{abstract}
Bone nonunion is observed when the healing of a fracture fails and all processes of biologic repair cease. It is a frequent complication during fracture treatment in small animals. Nonunions are classified as viable or nonviable, and most cases result from technical error (e.g., inadequate or inappropriate choice of the type of stabilization), poor vascularization, excessive distance between the fragments, infection, and systemic disease, or local as well as idiopathic factors. The diagnosis is made when there is no radiographic evidence of bone healing. This condition cannot be treated conservatively; rather, nonunions require surgical intervention involving removal of implants (besides exuberant callus removal), proper alignment, and compression of the fracture site. As bone nonunion remains a common problem in clinical practice, the objective of this paper is to review the pathophysiology and methods for treating of the condition.
\end{abstract}

Key words: Fracture. Nonunion. Radius and ulna. Dogs.

\section{Resumo}

A não união óssea acontece quando ocorre falha na consolidação óssea de uma fratura, onde todos os sinais de reparação aparentemente cessaram. É uma freqüente complicação do tratamento de fraturas em pequenos animais. As não uniões são classificadas em viáveis e não-viáveis e podem resultar de diversos fatores como estabilização inadequada, vascularização deficiente, distância excessiva entre os fragmentos, infecção, doença sistêmica ou local e fatores idiopáticos. A maior parte das não uniões resulta de escolha inadequada da forma de estabilização ou falha técnica por parte dos cirurgiões. $\mathrm{O}$ diagnóstico é quando radiograficamente não existem sinais de evolução da consolidação óssea. Esta afecção não pode ser tratada de forma conservadora, o tratamento é cirúrgico e é mandatória remoção dos implantes que falharam, remoção do calo exuberante, alinhamento adequado e compressão do foco de fratura. O objetivo deste trabalho é revisar a fisiopatologia, assim como as formas de tratamento desta afecção tão comum na prática clínica.

Palavras-chave: Fratura. Não união. Rádio e ulna. Cães.

\footnotetext{
${ }^{1}$ Discentes, Faculdade de Medicina Veterinária e Zootecnia da Universidade de São Paulo, FMVZ/USP, São Paulo, SP, Brasil. E-mail: jaquejfs@yahoo.com.br; idb_vet@yahoo.com.br

2 Prof., FMVZ/USP, São Paulo, SP, Brasil. E-mail: cassioaf@usp.br

${ }^{3}$ Prof $^{a}$, Universidade da República Oriental do Uruguai, UdelaR, Montevideu, Uruguai. E-mail: dizquierdo.caquias@gmail.com

* Author for correspondence
} 


\section{Introduction}

Fractures in long bones are common in small animal veterinary care (JOHNSON; HULSE, 2005), and the objective of the repair is to promote rigid fixation and proper alignment, allowing the quick return of the affected limb to its normal function (JACKSON; PACCHIANA，2004; JOHNSON; HULSE, 2005).

The physiological processes involved in fracture consolidation depend on adequate blood supply, which is articulated by the afferent, intermediate, and efferent vascular systems of the compact bone (PIERMATTEI; FLO, 1999). The long bones have afferent supply from the main nutrient artery, proximal and distal metaphyseal arteries, and periosteal arteries that penetrate the bone in areas of strong fascial connection. The direction of blood flow in the diaphysis is centrifugal, running from the spinal canal to the periosteum (JOHNSON; HULSE, 2005). The vessels in the compact bones are intermediate between the afferent and the efferent systems, and function as a vascular lattice where there are critical exchanges between the blood and surrounding tissues. This system consists of Havers' and Volkmann's cortical canals and tiny tubules, which carry nutrients to the osteocytes. The venous drainage of the cortical bone occurs in the periosteal surface (PIERMATTEI; FLO, 1999).

The fracture consolidation time in small animals is influenced by the type of bone involved, fracture type, patient age, method of osteosynthesis, and presence of systemic diseases (DENNY; BUTTERWORTH, 2006).

The speed of consolidation, often in weeks, allows the orthopedic surgeon to determine the expected time to fracture union. However, there is no consensus regarding the time required for fracture consolidation. Nonetheless, if the fracture has no radiographic signs of activity or formation of bone callus in the expected time, delayed union or nonunion should be considered. It is important to recognize early signs of complications in fracture consolidation, which allows for early correction of the problem and increases the chances of success (JACKSON; PACCHIANA, 2004).

Complications arising from the treatment of fractures include delayed union, nonunion, malunion, osteomyelitis, fracture disease, sarcoma associated with fracture, and fat embolism (DENNY; BUTTERWORTH, 2006).

\section{Complications in fracture consolidation}

Bone nonunion is defined as a failure in fracture consolidation, whereby all signs of repair apparently cease (JACKSON; PACCHIANA, 2004; MILLIS; JACKSON, 2003; ROVESTI, 2005).

The term "delayed union" is applicable when the healing time exceeds that expected for the specific type of fracture (ROVESTI, 2005). Over time, the fracture can progress to nonunion or complete consolidation (DENNY; BUTTERWORTH, 2006).

Over time, pseudarthrosis can occur because of movement at the location of nonunion. There is sclerosis of the bone ends, fibrocartilage formation between the ends, and fibrous capsule formation. Dogs may have reasonable function of the limb, and there may be significant movement at the site of the pseudoarthrosis, especially if it is close to the joint (MILLIS; JACKSON, 2003).

\section{Classification}

Traditionally, nonunions have been classified according to the Weber-Cech system, first described in 1976. This classification divides nonunions into two big groups: the biologically active (viable) and the biologically inactive (nonviable) (DENNY; BUTTERWORTH, 2006).

The nonunion can be hypertrophic, slightly hypertrophic, or oligotrophic. The hypertrophic nonunion has abundant bone callus, but does not form a bridge between the fracture fragments, 
often due to rotational instability (Figure 1). In slightly hypertrophic nonunion, there is some callus formation (without covering the fracture defect), but it is moderately unstable. By contrast, in the oligotrophic nonunion there is formation of little or no callus (JACKSON; PACCHIANA, 2004; MILLIS; JACKSON, 2003; PIERMATTEI, FLO, 1999; ROVESTI, 2005).

Figure 1. Radiographic images showing hypertrophic nonunion in dog humerus (A) and dog radio (B) and atrophic nonunion in dog radio and ulna $(\mathrm{C}$ and $\mathrm{D})$.

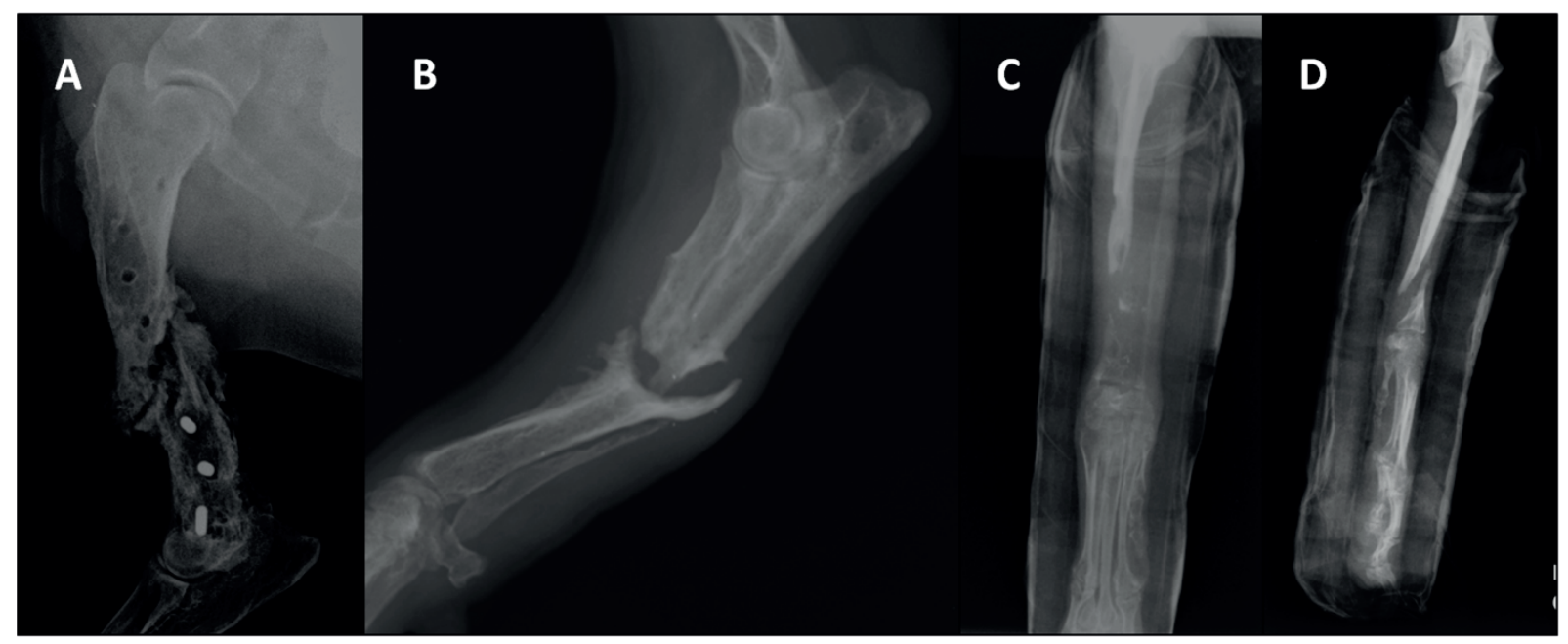

The nonviable nonunions can be considered dystrophic, atrophic, defective, or necrotic. Dystrophic nonunions are caused by impairment of the blood supply to the fracture fragments, so that the fragments do not participate in the consolidation and tend to result in obstruction. Necrotic nonunions are caused by loss of blood supply such that bone sequestra are formed and obstruct the union at the fracture site. Defective nonunions are formed when there is severe bone loss at the site, and the defect may exceed the body's ability to promote consolidation. Atrophic nonunion is the final evolution of the other three forms of nonviable union (DENNY; BUTTERWORTH, 2006; JACKSON; PACCHIANA, 2004; MILLIS; JACKSON, 2003; PIERMATTEI, FLO, 1999; ROVESTI, 2005) (Figure 1). The main type of nonviable nonunion is the atrophic form, which is common in small animals (mainly in small breeds), especially in radius and ulna fractures treated inappropriately or with extensive soft tissue manipulation, which may compromise the vascular supply (PIERMATTEI; FLO 1999).

It is worth considering that the biologically "active/inactive" and "viable/nonviable" terms are more appropriately related to cellular activity, which is best established with scintigraphic evaluation than by radiographic examination (DENNY; BUTTERWORTH, 2006; ROVESTI, 2005). The terminology used in these classifications can be confusing, since the term "nonviable" suggests that the consolidation will not occur, while "viable" suggests that it will occur. In fact, consolidation will not occur in any of these instances if there is no appropriate treatment (DENNY; BUTTERWORTH, 2006).

\section{Causes}

The nonunion can result from several factors such as inadequate stabilization, poor 
vascularization, excessive distance between fragments, infection, systemic or local disease, and idiopathic factors (DENNY; BUTTERWORTH, 2006). Most nonunions result from the wrong choice of the form of stabilization or technical failure by surgeons (JOHNSON; HULSE, 2005; ROVESTI, 2005).

Instability is the most common cause of nonunion, and generally results from inappropriate application of the implants, both in terms of choosing the wrong method, or incorrect placement. Infection can also interfere with repair, since it can cause lysis around the implants, resulting in loosening and repair failure (DENNY; BUTTERWORTH, 2006).

The presence of necrotic bone fragments, loose implant, or very large fracture defects are factors that can interfere with bone consolidation. Infection can contribute to aggravating bone necrosis, with the treatment involving local debridement, filling of the defect with cancellous bone grafting, and fracture stabilization (PATEL et al., 2000).

Poor vascularity at the fracture site may be due to trauma or excessive manipulation of soft tissue during fracture repair. Therefore, the optimization of neovascularization by stabilizing the focus and minimizing tissue surgical trauma are essential for ensuring successful fracture repair (DENNY; BUTTERWORTH, 2006). The radius distal region in miniature dog breeds has limited blood supply, and fractures of the radius distal region of bone in these breeds have a marked propensity to become nonunions (DELLA NINA et al., 2007; ROVESTI, 2005).

When a systemic disease is associated with the bone nonunion, a correspondingly systemic treatment is needed before instituting treatment for the fracture. In the case of local disease, the disease will often be neoplastic, and the prognosis will be reserved (DENNY; BUTTERWORTH, 2006).

\section{Diagnosis}

The animal usually has claudication of the limb affected by the nonunion, and may reach functional impotence. Muscle atrophy and joint stiffness are usually clear, although the pain may be less intense than in the case of delayed union (ROVESTI, 2005). Pain and lameness may not be present when the nonunion is chronic (JACKSON; PACCHIANA, 2004). Local movement may be present, although in many cases instability is not clinically evident. The presence of infection can be further complicated and is usually associated with increased discomfort (ROVESTI, 2005).

Fracture nonunions are diagnosed when there is radiographic evidence that bone consolidation is not occurring, or there is no indication that it will occur (JOHNSON; HULSE, 2005). The diagnosis is made with an emphasis on history as well as clinical and radiographic signs (JACKSON; PACCHIANA, 2004). The radiographic features of nonunion include defects between the ends of the fracture, closed medullary cavity, smooth surfaces of the fracture fragments, sclerosis, hypertrophy, or atrophy of bone fragments (DENNY; BUTTERWORTH, 2006).

Radiographically, the fracture ends in hypertrophic nonunion are similar to an elephant foot, with abundant callus (JACKSON; PACCHIANA, 2004; ROVESTI, 2005). In the hypertrophic nonunion, the fracture ends are like a horse's hoof, with little callus. The ends of the oligotrophic nonunion are rounded and, in the dystrophic union, the medullary canal is patent at one end, of the fracture and closed at the other. Bone sequestra that prevent the consolidation will be present in necrotic nonunion. A defective nonunion forms a gap at the fracture site such that the consolidation cannot occur. Atrophic nonunions have closed bone ends (JACKSON; PACCHIANA, 2004). 


\section{Treatment}

Initial treatment involves removal of the implants that have failed, removal of exuberant callus for proper alignment, and compression of the fracture site (DENNY; BUTTERWORTH, 2006). The periodic compression of the fracture site is one of the options indicated for the treatment of bone nonunion (ROVESTI, 2005).

Bone nonunion cannot be treated conservatively, and surgery is indicated in all cases. The bone ends must be rectified, and any nonviable tissue must be removed. The fixation used must counteract the forces that underlie instability, such as shear, affixing, rotation, and bending. Any ongoing infection should be treated appropriately and bone graft placement is required (JACKSON; PACCHIANA, 2004).

In nonviable unions, any ischemic bone fragments must be removed. However, the equalization of fracture edges or the filling of the site with autologous bone graft, is not necessary, whereas compression may be only enough to create a favorable environment for consolidation (PIERMATTEI et al., 2006).

Nonviable nonunions require removal of devitalized tissue with osteotomy of the edges to facilitate alignment, opening of the medullary canal, rigid fixation, compression of the fracture site, and placement of cancellous bone graft. The most widely used implant is the plate with compressive effect, which is versatile and comfortable for the patient. After consolidation, the implant should be removed, especially in cases of osteomyelitis (JOHNSON; HULSE, 2005).

Circular external skeletal fixators (CESF) allow compression of the fracture site, thus stimulating osteogenesis through axial micro-movements that promote consolidation (FERRIGNO et al., 2010; JOHNSON; HULSE, 2005), and enabling the execution of distraction osteogenesis in the case of major failures. CESF are also indicated in cases of infection, due to limited contact with the bone when compared to the plates. However, they are uncomfortable for the patient, require appropriate management by the owner (bandages), and the placement technique is complex (JOHNSON; HULSE, 2005).

Ferrigno et al. (2010) reported the use of CESF for treating a tibia nonunion in a dog, and concluded that the fixator facilitates the treatment of nonunions, and its use is versatile since it can be applied in small fragments. Patel et al. (2000) reported consolidation of humerus nonunion in 15 of 16 patients, with pain relief and improvement in function using this method of osteosynthesis. They noted that, although the method has some disadvantages to patients and is costly and laborious, it is an effective form of treatment for cases of nonunion that failed in previous surgical treatments. Rahal et al. (2005a) concluded that the CESF can be used for treating delayed consolidation and nonunion, but it is difficult to install in small breed dogs.

Wu and Shih (1992), in a study of 84 femoral nonunions, mentioned that the Kuntscher nail and the interlocking intramedullary nail had fewer complications, shorter surgery time, and less blood loss. The Kuntscher nail was preferred in the region of the femoral neck when there was no shortening of the limb, whereas the intramedullary nail was preferred above or below this area or when elongation was indicated.

Sampaio et al. (2010) concluded that the treatment of radioulnar chronic fracture nonunion in a dog, with the bone plate and cancellous bone graft, was highly effective. Della Nina et al. (2007) used bone morphogenetic protein (BMP) in a comparative study of osteosynthesis with the plate, and osteosynthesis with the plate associated with graft in distal radioulnar fractures in a Pinscher breed dog, and demonstrated that bone morphogenetic protein significantly decreased the time of bone callus formation.

Ferrigno et al. (2008) studied 196 cases of radio and ulna diaphyseal fractures in small dogs and concluded that osteosynthesis by screwed plate or 
external skeletal fixation, have better results when compared to external immobilization regardless of pattern or arrangement of the fracture, and that this is more relevant in dogs weighing less than $6.0 \mathrm{~kg}$.

Rahal et al. (2005b) reported that the pin-resin skeletal fixator in type II configuration, assisted by autologous cancellous bone graft, is a simple, effective, and low-cost option for the treatment of complications secondary to the inadequate immobilization of radius and ulna fractures in dogs.

Bone grafts are indicated in cases of osteomyelitis or nonunion, as a stimulus for bone consolidation in the preservation of limbs and corrective osteotomies (PADILHA FILHO et al., 2008). Gardner et al. (2008) evaluated the evolution of 31 patients with distal femoral pseudarthrosis, who underwent a standardized treatment plan that included open reduction, internal fixation, bone grafting, and placement of compression screw. At the end of the study, the union rate was $97 \%$ and the average duration of treatment was 15.9 weeks, with complete return to functional status in $84 \%$ of the cases.

The BMP serves as a mediator of bone regeneration, and stimulates mesenchymal pluripotent stem cells to proliferate and differentiate into osteoblastic, chondroblastic, or fibroblastic lineages at the fracture site (MILOVANCEV et al., 2007). Heckman et al. (1991) produced a model of nonunion in diaphysis in dogs and tested the osteoinductive power of morphogenetic protein in these animals. The authors noted that this led to bone union when associated with polymer of polylactic acid, but not when associated with bovine demineralized bone extracted by guanidine. Milovancev et al. (2007), based on experience with 4 dogs, found that the local application of recombinant human bone morphogenetic protein-2 (rhBMP-2) to the fracture or osteotomy site through open or minimally invasive approach (e.g., percutaneous injection guided by fluoroscopy), is an effective treatment modality for bone delayed union or nonunion. Arnault et al. (2011) reported the successful use of rhBMP-2 in the treatment of radio and ulna nonunion, secondary to the fracture caused by firearm shooting, which stabilized with the use of a circular external fixator in a cat.

Bone grafts are indicated when it is desired to promote, by the early formation of bridging callus, the consolidation of delayed unions, nonunions, osteotomy, and arthrodesis (PIERMATTEI; FLO, 1999). Autologous bone marrow graft applied percutaneously is an effective and safe method for the treatment of nonunion in tibial diaphysis (HERNIGOU et al., 2005). Therapy with skeletal stem cells from bone marrow proved effective in osteogenic stimulation of fracture nonunion through a noninvasive method, by promoting bone union in patients who had a one-year or longer fracture and in whom several previous surgeries had failed (ZAMPROGNO, 2007).

Cox et al. (2010) studied bone markers in fracture consolidation, and concluded that the available evidence does not support the routine use of these markers to evaluate fracture healing, and the ability to measure interventions for accelerating fracture consolidation has not been established.

Extracorporeal shockwave therapy (ESWT) is effective in promoting bone consolidation in nonunion of long bones, with a union rate of $79 \%$. These results are comparable to the treatment with open reduction and bone grafting, without surgical risks. Bone healing promoted by ESWT is associated with systemic elevation in serum levels of nitric oxide (NO) and osteogenic growth factors. Local bone stimulation of ESWT may reflect the systemic effects of osteogenesis after the treatment. Serum levels of NO and osteogenic growth factors can be used as predictors in the evaluation of nonunion bone consolidation in long bones (WANG et al., 2009). Souza et al. (2011) reported the use of ESWT in two dogs, with great radiographic improvement of bone aspect, as well as bone healing in one of the cases, suggesting that ESWT can be an alternative 
in cases of nonunion. However, they suggested the need for further studies to assess the treatment protocol used.

Carvalho et al. (2002) studied the nonunion treatment with magnetic fields, ultrasound, and helium-neon laser radiation. They obtained positive effects with this noninvasive technique by means of inductive stimuli, which created magnetic fields around the nonunion region. Ultrasound is a form of mechanical energy that propagates by acoustic pressure waves of high frequency. When the waves are transmitted to the interior of the body, they promote micro-deformations in the stimulated bone region, and are capable of generating stimuli to accelerate or initiate the osteogenic process. Studies have shown that low-intensity pulsed ultrasound (30 $\mathrm{mW} / \mathrm{cm}^{2}$, repetition frequency of $1 \mathrm{kHz}$, duty cycle of $20 \%$ and 20 minutes per day) may accelerate bone regeneration in clinical cases of nonunions with decreased consolidation time. Studies using helium-neon laser radiation showed beneficial osteogenesis effects, with increased vascularization and acceleration in the rate of bone formation.

\section{Conclusion}

Complications in the treatment of fractures are frequent. However, these can be minimized by appropriate treatment procedures, and the use of good quality metal implants. Furthermore, the consequences on patients can be reduced through early diagnosis and treatment. Adherence to good surgical techniques, proper choice of the fracture fixation method, and knowledge of the local anatomical landscape are essential for prevention of nonunions.

\section{References}

ARNAULT, F.; MAITRE, P.; CACHON, T.; CAROZZO, C.; FAU, D.; GENEVOIS, J. P.; VIGUIER, E. Treatment of a nonunion, secondary to gunshot fracture, of the distal radius with circular external fixation and rhBMP-2 in a cat. Veterinary and Comparative Orthopaedics
Traumatology, Stuttgart, v. 24, n. 4, p. 289-293, 2011.

CARVALHO, D. C. L.; ROSIM, G. C.; GAMA, L. O. R.; TAVARES, M. R.; TRIBIOLI, R. A.; SANTOS, I. R.; CLIQUET JÚNIOR, A. Tratamentos não farmacológicos na estimulação da osteogênese. Revista Saúde Pública, São Paulo, v. 36, n. 5, p. 647-654, 2002.

COX, G.; EINHORN, T. A.; TZIOUPIS, C.; GIANNOUDIS, P. V. Bone-turnover markers in fracture healing. The Journal of Bone and Joint Surgery, Needham, v. 92-B, n. 3, p. 329-334, 2010.

DELLA NINA, M. I.; SCHMAEDECKE, A.; ROMANO, L.; FERRIGNO, C. R. A. Comparação de osteossíntese com placa e osteossíntese com placa associada a enxerto de proteína morfogenética óssea em fratura bilateral distal de rádio e ulna em cão - Relato de Caso. Brazilian Journal Veterinarian Research Animal Science, São Paulo, v. 44, n. 4, p. 297-303, 2007.

DENNY, H. R.; BUTTERWORTH, S. J. Cirurgia ortopédica em cães e gatos. 4. ed. São Paulo: ROCA, 2006. 504 p.

FERRIGNO, C. R. A.; SCHMAEDECKE, A.; PATANÉ, C.; BACCARIN, D. C. B.; SILVEIRA, L. M. G. Estudo crítico do tratamento de 196 casos de fratura diafisária de rádio e ulna em cães. Pesquisa Veterinária Brasileira, Seropédica, v. 28, n. 8, p. 371-374, 2008.

FERRIGNO, C. R. A.; CUNHA, O.; IZQUIERDO, D.; FERRAZ, V. C. M.; ITO, K. C.; MARIANI, T. C.; DELLA NINA, M. I. Fixador externo circular (Ilizarov) em não união de tíbia - Relato de caso. Medvep - Revista Científica de Medicina Veterinária - Pequenos Animais e Animais de Estimação, Curitiba, v. 8, n. 25, p. 315-318, 2010.

GARDNER， M. J.; TORO-ARBELAEZ， J. B.; HARRISON, M.; HIERHOLZER, C.; LORICH, D. G.; HELFET, D. L. Open reduction and internal fixation of distal femoral nonunions: long-term functional outcomes following a treatment protocol. The Journal of Trauma, Alphen aan den Rijn, v. 62, n. 2, p. 434-438, 2008.

HECKMAN, J. D.; BOYAN, B. D.; AUFDEMORTE, T. B.; ABBOTT, J. T. The use of bone morphogenetic protein in the treatment of non-union in a canine model. Journal of Bone and Joint Surgery, Needham, v. 73, n. 3, p. 750-764, 1991.

HERNIGOU, P. H.; POIGNARD, A.; BEAUJEAN, F.; ROUARD, H. Percutaneous autologous bone marrow grafting for nonunions - Influence of number and concentration of progenitor cells. The Journal of Bone and Joint Surgery, Needham, v. 87-A, n. 7, p. 1430-1437, 2005. 
JACKSON, L. C.; PACCHIANA, P. D. Common complications of fracture repair. Clinical Tech Small Animal Practice, Amsterdam, v. 19, n. 3, p. 168-179, 2004.

JOHNSON, A. L.; HULSE, D. A. Fundamentos da cirurgia ortopédica e tratamento de fraturas. In: FOSSUM, T. W. Cirurgia de pequenos animais. 2. ed. São Paulo: ROCA, 2005. p. 823-899.

MILLIS, D. L.; JACKSON, A. M. Delayed unions, nonunions and malunions. In: SLATTER, D. Textbook of small animal surgery. $3^{\text {th }}$ ed. Philadelphia: WB Saunders, 2003. p. 1849-1861.

MILOVANCEV, M.; MUIR, P.; MANLEY, P.; SEEHERMAN, H. J.; SCHAEFER, S. Clinical application of recombinant human bone morphogenetic protein-2 in 4 dogs. Veterinary Surgery, Davis, v. 36, n. 2, p. 132-140, 2007.

PADILHA FILHO, J. G.; PENHA, L. H. C.; SOUZA, S. F. Uso do enxerto ósseo cortical bovino conservado em glicerina a $98 \%$ na osteotomia femoral em gatos. Ciência Animal Brasileira, Goiânia, v. 9, n. 4, p. 1071-1078, 2008.

PATEL, V. R.; MENON, D. K.; POOL, R. D.; SIMONIS, R. B. Nonunion of the humerus after failure of surgical treatment. The Journal of Bone and Joint Surgery, Needham, v. 82-b, n. 7, p. 977-983, 2000.

PIERMATTEI, D. L.; FLO, G. L. Manual de ortopedia e tratamento das fraturas dos pequenos animais. 3. ed. São Paulo: Manole, 1999. 694 p.

PIERMATTEI, D. L.; FLO, G. L.; DeCAMP, C. E. Handbook of small animal orthopedics and fracture repair. $4^{\text {th }}$ ed. Missouri: Saunders Elsevier, 2006. 818 p.

RAHAL, S. C.; HETTE, K.; ESTANISLAU, C. A.; VULCANO, L. C.; FEIO, A. M.; BICUDO, A. L. C. Fixador esquelético pino-resina acrílica e enxerto ósseo esponjoso no tratamento de complicações secundárias à imobilização inadequada de fratura do rádio e ulna em cães. Ciência Rural, Santa Maria, v. 35, n. 5, p. 1109$1115,2005 b$.
RAHAL, S. C.; VOLPI, R. S.; HETTE, K.; VULCANO, L. C.; BÜTTNER, R. C. Emprego de fixador externo circular no tratamento de complicações de fraturas do rádio e ulna em cães de raças pequenas. Ciência Rural, Santa Maria, v. 35, n. 5, p. 1116-1122, 2005 a.

ROVESTI, G. L. Nonunions. In: JOHNSON, A. L.; HOULTON, J. E. F.; VANNINI, R. Ao principles of fracture management in the dog and cat. Clavadelerstrasse: Thieme, 2005. p. 402-408.

SAMPAIO, M. I. R.; SILVA, C. E. S.; ARAÚJO, B. M.; GOMES, J. A. A.; SILVA, A. C.; FERNANDES, T. H. T.; FIGUEIREDO, M. L.; TUDURY, E. A. Tratamento cirúrgico de não união crônica (30 meses) de fratura radio-ulnar em cão - relato de caso. In: JORNADA DE ENSINO, PESQUISA E EXTENSÃO - JEPEX, 10., 2010, Recife. Anais... Recife: UFRPE, 2010. p. 20-21.

SOUZA, A. N. A.; MATERA, J. M.; FERRIGNO, C. R. A.; HAGEN, S. C. F.; FERREIRA, M. P.; CUNHA, O. Avaliação radiográfica após tratamento de ondas de choque extracorpóreo em casos de não união: relato de casos. In: CONGRESSO PAULISTA DE CLÍNICOS VETERINÁRIOS DE PEQUENOS ANIMAIS, 11., 2011, São Paulo. Anais... São Paulo: Anclivepa, 2011. p. 89-91.

WANG, C. J.; YANG, K. D.; KO, J. Y.; HUANG, C. C.; HUANG, H. Y.; WANG, F. S. The effects of shockwave on bone healing and systemic concentrations of nitric oxide (NO), TGF-beta 1, VEGF and BMP-2 in long bone non-unions. Nitric Oxide, Rochester, v. 20, n. 4, p. 283303, 2009.

WU, C. C.; SHIH, C. H. Treatment of 84 cases of femoral nonunion. Acta Orthopaedica Scandinavica, Copenhagen, v. 63, n. 1, p. 57-60, 1992.

ZAMPROGNO, H. Células tronco esqueléticas para o tratamento da não união de fraturas. Acta Scientiae Veterinariae, Porto Alegre, v. 35, p. 289-290, 2007. Suplemento 2. 